\title{
Performed Observation Method Code
}

National Cancer Institute

\section{Source}

National Cancer Institute. Performed Observation Method Code. NCI Thesaurus. Code C93935.

A coded value specifying the technique used to perform the observation. 